\title{
Removal of Heavy Metals using the Isolates of Aspergillus sp. Isolated from Contaminated Pulp and Paper Mill Sludge
}

\author{
M. Ezhilvanan ${ }^{1}$, S. F. Lesley Sounderraj ${ }^{1}$ and Nancy Lesley ${ }^{2}$ \\ ${ }^{1}$ Department of Zoology, Voorhees College, Vellore, Tamil Nadu, India \\ ${ }^{2}$ Department of Statistics, Presidency College, Chennai, Tamil Nadu, India \\ *Corresponding author
}

\section{A B S T R A C T}

\section{Keywords}

Bioaccumulation, Biosorption, Pulp and paper mill sludge (PMS), Pulp and paper mill effluent (PME)

Article Info

Accepted:

12 March 2021

Available Online:

10 April 2021
Industrial discharges, in the form of effluent is one of the greater problems causing serious environmental pollution. Pulp and paper mills are categorized as one of the 12 most polluting industries containing heavy metals like $\mathrm{Cu}, \mathrm{Zn}$, $\mathrm{Cd}, \mathrm{Pb}, \mathrm{Cr}$ and $\mathrm{Mn}$. The removal and recovery of heavy metals from effluent is indispensable for the protection of environment. Biological methods such as bioaccumulation and biosorption of heavy metals provide an alternative to physical and chemical methods for waste water treatment. In the present study, A.flavus and A.fumigatus isolated from pulp and paper mill sludge showed tolerance and accumulation of toxic metals from synthetic medium and paper mill effluent. Effect of heavy metal ions on fungal growth in terms of their biomass (dry weight) was determined and conformed energetic fungal growth after increasing the concentration of $\mathrm{Pb}^{2+}$ and $\mathrm{Zn}^{2+}$ point out the importance of these two fungi for bioremediation. Heavy metal reductions were found significant $(\mathrm{P}<0.001)$ in paper mill effluent treated with A.flavus and A.fumigatus, and accumulated maximum $\mathrm{Pb}$ followed by $\mathrm{Cu}, \mathrm{Zn}, \mathrm{Cd}, \mathrm{Cr}$ and Mn metals were noticed.

\section{Introduction}

A serious problem of environmental pollution has arisen in recent years, due to heavy metals resulting from many industrial effluents such as smelting, mining, metal plating, pigment and metallurgical (Akar and Tunali, 2006). The effluents released from the paper mills contain environmentally hazardous heavy metals and other organic toxicants (Verma et al., 2005). The concentration of $\mathrm{Cu}, \mathrm{Cr}(\mathrm{VI})$ and $\mathrm{Pb}$ was significantly high in paper mill effluent due to its application as catalyst, pigments, wood preservatives and corrosion inhibitors (Goel, 1996).According to Leung et al., (2000) and Lacina et al., (2003), the fungi especially Aspergillus species have been proved to be more efficient and economical in removal of 
metals and organic toxicants from (dilute) aqueous solutions compared to conventional methods, because of their filamentous and spherical morphological mycelia and high cell wall percentage with functional groups like amine, carboxyl and phosphate which influence the heavy metal adsorption. Aspergillus sp. accumulate micronutrients such as $\mathrm{Cu}, \mathrm{Zn}, \mathrm{Mn}$ and toxic metals like $\mathrm{Ni}$, $\mathrm{Cd}, \mathrm{Sn}$ and $\mathrm{Hg}$ in amounts higher than the nutritional requirement. In light of the above, the present study was carried out to investigate the metal accumulation and biosorption potential of A.flavus and A.fumigatus isolated from pulp and paper mill sludge.

\section{Materials and Methods}

\section{Sample collection}

The untreated paper mill effluent (PME) was collected from the final discharge point (Plate: 1, $2 \& 3$ ) of the effluents of Seshasayee Paper, Board and Pulp mill Ltd, Pallipalayam, situated at $11^{\circ} 20^{\prime} 27^{\prime}$ 'North $77^{\circ} 43^{\prime} 02^{\prime}$ 'East and north-west of Erode, Tamil Nadu, India, which produces board, printing and writing paper as its main products from bagasse based integrated mill, having an installed capacity of 1,20,000 t/annum. The samples were collected(Sludge and effluent) in dry sterilized Petridish and 20 litres polypropylene container respectively. Samples were preserved at $4^{\circ} \mathrm{C}$ in the refrigerator to retard biological activity prior to use till its processing for isolation of heavy metals resistant fungi.

\section{Physico-chemical analysis of paper mill effluent}

The sample of untreated paper mill effluents were analysed using the standard methods prescribed by APHA (2005) for different Physico-chemical parameters, viz. colour, $\mathrm{pH}$, turbidity, total dissolved solids(TDS), calcium, Magnesium, Reactive Silica $\mathrm{SiO}_{2}$, chemical oxygen demand (COD), Chlorides, sulphate, potassium, sodium, manganese, zinc, chromium, copper, cadmium and Lead.

\section{Determination of heavy metals}

Metal treated filtrate medium was digested using $5 \mathrm{ml}$ of concentrated $\mathrm{HNO}_{3}$ and boiling chips. The content was boiled and evaporated to $16-20 \mathrm{ml}$ on hot plate. $5 \mathrm{ml}$ of concentrated $\mathrm{HCl}$ was added and boiled till sample become clear and brownish fume was evident. Then dried container was cooled, diluted with $100 \mathrm{ml}$ double distilled water and filtered through Whatman's No.1 filter paper.

Concentration of heavy metals in the filtered solution was determined using AAS instrument (Srivastava and Thakur, 2006). The dried fungal matt was crushed in pestle and mortar. Ground material was placed in conical flask and 5:5 ratio of nitric/perchloric acid mixture was added. The content of the flask was placed on hot plate until the production of red nitrous fumes ceased and liquid becomes colourless. Finally the container was cooled, diluted to $100 \mathrm{ml}$ with double distilled water and filtered through Whatman's No.1 filter paper to analyse heavy metals content using AAS instrument (Juwarkar, 1988).

\section{Isolation and Identification of heavy metal tolerance strains}

$10 \mathrm{~g}$ of sludge sample was serially diluted and made up to $10^{-1}$ to $10^{-6}$ using sterile distilled water. A sample of $0.1 \mathrm{ml}$ from the appropriate dilution was spread on CzapeckDox's agar plates and the plates were incubated at room temperature for 5-7 days. After incubation, the distinct colonies were sub cultured continuously on the suitable medium for the isolation of pure culture. The pure culture strains of isolated fungi were tested for heavy metal tolerance by placed these stains in CzapeckDox's agar medium supplemented 
with individual heavy metals in the form of salts $\mathrm{ZnSO}_{4}, \mathrm{CdCl}_{2}, \mathrm{~Pb} \mathrm{NH_{3 }}, \mathrm{K}_{2} \mathrm{Cr}_{2} \mathrm{O}_{7}$ and $\mathrm{CuSO}_{4} 5 \mathrm{H}_{2} \mathrm{O}$ separately at the concentration of $50 \mathrm{ppm}$. The plates were incubated for 5-7 days at $28^{\circ} \mathrm{C}$ for their growth. Isolated pure colonies were maintained on CzapeckDox's agar slants and sub-culturing was carried once a month by growing them at $28^{\circ} \mathrm{C}$ for 7 days and stored in the refrigerator for further use. The spore suspensions were stored as stock culture in $20 \% \mathrm{~W} / \mathrm{V}$ glycerol at $-20^{\circ} \mathrm{C}$.

\section{Screening of potential strains for metal removal}

Different fungal isolates from paper mill sludge were grown on the CzapeckDox's agar media(Plate. 7 and 8). Screening of fungal isolates capable for heavy metal removal was carried out using the loopful of fungal growth, from grown culture were embedded on CZA plate containing stress amount of PME and incubated at $28^{\circ} \mathrm{C} \pm 1^{\circ} \mathrm{C}$ for 5 days.

Heavy metal degrading ability of each fungal isolate was identified by the presence of clear zone around their colonies. These fungal stains were identified based on their morphology and reproductive structural characteristics (Nagamani et al., 2006).

\section{Preparation of metal solutions}

Stock metal solutions of $1000 \mathrm{mg}^{-}$ ${ }^{1}$ concentration of $\mathrm{Zn}, \mathrm{Cd}, \mathrm{Pb}, \mathrm{Cu}$ and $\mathrm{Cr}$ were prepared by dissolving analytical grade of salts of $\mathrm{ZnSO}_{4} 6 \mathrm{H}_{2} \mathrm{O}, \mathrm{CdCl}_{2},\left(\mathrm{CH}_{3} \mathrm{COO}\right)_{2}$, $\mathrm{Pb}_{3} \mathrm{H}_{2} \mathrm{O}, \mathrm{CuSO}_{4} 5 \mathrm{H}_{2} \mathrm{O}$ and $\mathrm{K}_{2} \mathrm{Cr}_{2} \mathrm{O}_{7}$ separately in 1 litre of double distilled water. The desired $\left(100,250,500\right.$ and $\left.1000 \mathrm{mgl}^{-1}\right)$ concentrations of working metal solution were prepared from stock solution. Before mixing with media and fungal culture, $\mathrm{pH}$ of each test metal solution was adjusted to desirable value with that of media using $0.1 \mathrm{~N} \mathrm{HCl}$ and $0.1 \mathrm{~N} \mathrm{NaOH}$.
Bioaccumulation of metals from synthetic medium and paper mill effluent

The spores from a fully sporulated slants of Aspergillus flavus and A.fumigatus were dispersed separately in $10 \mathrm{ml}$ of sterile water containing $0.1 \%$ Tween 80 and by rubbing the spore with a sterile loop under aseptic conditions. The spore suspension showed $1 \times 10^{6}$ spores $/ \mathrm{ml}$ were inoculated in to the medium in $250 \mathrm{ml}$ Erlenmeyer's flask containing $100 \mathrm{ml}$ of specific production medium (Potato Dextrose Agar for A.flaveus and CzapeckDox's for A.fumigatus) supplemented with 100,250,500 and $1000 \mathrm{mg}$ $1^{-1}$ concentrated of each heavy metal. Inoculated flasks were incubated on reciprocating shaker at $200 \mathrm{rpm}$ at $28^{\circ} \mathrm{C}$ for 7 days with control flask containing spore inoculated medium without metal salts. Whereas from accumulation of metal from PME, 100mg of biomass of Aspergillus flavus and Aspergillus fumigatus were inoculated separately into $100 \mathrm{ml}$ of untreated pulp and paper mill effluent enriched with $0.1 \%$ of glucose and tryptone for carbon and nitrogen substrates in $250 \mathrm{ml}$ of Frlenmeyers flask. Inoculated samples were incubated with control containing $100 \mathrm{ml}$ of treated effluent without fungal biomass. All the flasks were incubated at $28{ }^{\circ} \mathrm{C}$ for 72 hours to check fungal growth and its metal uptaking potential. After incubation concentrations of heavy metals in fungal treated effluent and control was determined to find out any significant heavy metals reduction by fungi compared with untreated paper mill effluent.

\section{Determination of dry weight of fungal biomass}

After incubation period, the fungal matt was harvested from working culture by sieving through whatman's filter paper and filtrate medium was collected. Fungal matt was thoroughly washed twice with distilled water 
to remove non biomass ash and dried in an oven at $80^{\circ} \mathrm{C}$ for 12 hours and constant dry weight was taken.

\section{Optimization of parameters}

Batch forms of experiments were conducted in Erlenmeyer flasks to determine the effects of $\mathrm{p}^{\mathrm{H}}$, temperature and contact time, metal ions and biomass concentration on bioaccumulation of heavy metals for optimization of parameters in heavy metals bioaccumulation study, the 7 day old fungal spores of Aspergillus flavus and Aspergillus fumigatus was inoculated into $100 \mathrm{ml}$ of selective medium (PDA and CZA respectively) containing $100 \quad \mathrm{mg}^{-1}$ concentration of each heavy metal in $250 \mathrm{ml}$ Erlenmeyer flask. After optimization, the conditions of $\mathrm{pH}$, temperature and incubation period was followed for further experiments (removal of heavy metals from untreated PME effluent) and the heavy metals content in filterate medium was determined using AAS (Srivastava and Thakur, 2006).

\section{Results and Discussion}

\section{Physico-chemical characteristics of} untreated pulp and paper mill effluent

The physical-chemical characteristics of untreated pulp and paper mill effluent are given in the Table 1 . The heavy metal characteristics are given in the Table 2.

\section{Heavy Metal tolerance of Fungal Isolates}

Effect of $\mathrm{Zn}, \mathrm{Cd}, \mathrm{Pb}, \mathrm{Cu}$ and $\mathrm{Cr}$ ions on fungal growth in terms of the dry weight of the their biomass was investigated at increasing concentrations of 100 to $1000 \mathrm{mg} \mathrm{l}^{-1}$ (Fig.1a,b). A.flavus showed heavy metal tolerance upto $1000 \mathrm{mg} \mathrm{l}^{-1}$ of $\mathrm{Zn}$ and $\mathrm{Pb}$ followed by $250 \mathrm{mg}$ $\mathrm{l}^{-1} \mathrm{Cd}, 100 \mathrm{mg}^{-1}$ of $\mathrm{Cu}$ and $\mathrm{Cr}$. A.fumigatus tolerated $1000 \mathrm{mg} \mathrm{l}^{-1}$ of $\mathrm{Zn}$ and $\mathrm{Pb}$ followed by $250 \mathrm{mg} \mathrm{l}^{-1}$ of $\mathrm{Cd}, \mathrm{Cu}$ and $\mathrm{Cr}$. There was an increase in fungal growth in the media amended with $\mathrm{Pb}$ and $\mathrm{Zn}$ compared with control. The biomass of A.flavus and A.fumigatus was observed to be high in 100 $\mathrm{mg}^{-1}$ concentration of $\mathrm{Pb}$ followed by $\mathrm{Zn}>\mathrm{Cr}>\mathrm{Cu}>\mathrm{Cd}$. The biomass of A.flavus and A.fumigatus decreased with increasing metal concentration. The vigorous fungal growth towards increasing concentration of $\mathrm{Pb}$ and $\mathrm{Zn}$ point out the importance of these metals in fungal growth and to exploit these fungi in bioremediation of heavy metals contaminated effluent.

The result showed that increasing the concentration of heavy metals had influence on the fungal biomass and heavy metals accumulation. Both A.flavus and A.fumigatus showed resistance towards $\mathrm{Pb}$ and $\mathrm{Zn}$ at high concentration but could not accumulate these metals at higher concentrations. Similarly, Zetic et al., (2001) reported that the effect of heavy metals on fungal growth was variable and depends on the type of metal and its concentration in the medium. The toxicity effect of some heavy metals like $\mathrm{Cd}, \mathrm{Cu}$ and $\mathrm{Cr}$ on fungal growth is due to their strong binding affinity with the cell membrane components which in turn damage the cell integrity and impairment of cell function (Chen and Wang, 2007). This might be the reason for the decreased level of fungal growth which are treated with $\mathrm{Cd}, \mathrm{Cu}$ and $\mathrm{Cr}$.

\section{Heavy metal accumulation}

In the present study, the isolated fungal species of A.flavus and A.fumigatus from paper mill sludge showed tolerance and accumulation of toxic heavy metals such as $\mathrm{Zn}, \mathrm{Cd}, \mathrm{Pb}, \mathrm{Cu}$ and $\mathrm{Cr}$ from synthetic medium and paper mill effluent. The metal tolerance and loading capacity of living cells of A.flavus and A.fumigatus is shown in (Fig. 2a, b). A.flavus accumulated high amount of $\mathrm{Pb}$ 
$(88.31 \%)$ followed by $\mathrm{Zn}(48.66 \%)>\mathrm{Cr}$ $(46 \%)>\mathrm{Cu}(36 \%)$ and $\mathrm{Cd}(32.17 \%)$ from the concentration of $100 \mathrm{mg} \mathrm{l}^{-1}$ of metal solution. Whereas metal uptake from increased concentrations of metal solution such as 250 , 500 and $1000 \mathrm{mg} \mathrm{l}^{-1}$ was found as follows: $\mathrm{Pb}$ (70.6\%),> Zn (40.22\%) > Cd (17.60\%), Pb $(56.77 \%)>(\mathrm{Zn} 25.3 \%)$ and $\mathrm{Pb}(32.4 \%)>\mathrm{Zn}$ $(20.27 \%)$ respectively. The order of heavy metal accumulation by A.fumigatus showed high efficiency towards $\mathrm{Pb}(89 \%)$ followed by $\mathrm{Zn}(48 \%)>\mathrm{Cu}(42.33)>\mathrm{Cr}(39.6 \%)>\mathrm{Cd}$ $(37.75 \%)$ Whereas metal accumulation from 250 and $500 \mathrm{mg} \mathrm{l}^{-1}$ of metal solution was found in the following order: $\mathrm{Pb}(63.3 \%)>\mathrm{Zn}$ $(40.46 \%)>\mathrm{Cu}(30.12 \%)>\mathrm{Cr}(23.35 \%)>\mathrm{Cd}$ (22.45\%) and $\mathrm{Pb}(61.56 \%), \mathrm{Zn}(26.27 \%)$ respectively. However, A.fumigatus accumulated $\mathrm{Pb}(41.10 \%)$ and $\mathrm{Zn}(24.18 \%)$ from the concentration of $1000 \mathrm{mg} \mathrm{l}^{-}$ ${ }^{1}$.Thippeswamy et al., (2012) reported the accumulation of $\mathrm{Pb}, \mathrm{Zn}, \mathrm{Cu}$ and $\mathrm{Ni}$ by A.Flavus from synthetic medium. In the present study, A.fumigatus showed comparatively higher resistance, growth and uptake of $\mathrm{Pb}$ and other metal ions compared with A.flavus. In both the organisms, the accumulation of $\mathrm{Pb}$ was found to be high as compared to other metal ions.

However in the presence of $\mathrm{Cr}$ and $\mathrm{Cd}$, the growth of A.flavus was inhibited. There was an increase in fungal growth in the media supplemented with $\mathrm{Pb}$ and $\mathrm{Zn}$ compared to control in A.flavus and A.fumigatus. In earlier findings Akar and Tunail (2006) reported only $22 \% \mathrm{~Pb}$ and $20 \% \mathrm{Cu}$ biosorption by A.flavus. Sugasini et al., (2014) investigated the biosorption potential of Aspergillus sp. isolated from tannery effluent. In the present study, both A.flavus and A.fumigatus showed high adsorption capacity of chromium from PME, it may due to the development of adaptation of this fungi to different heavy metal concentrations of PME compared to single metal effluent.

\section{Optimization conditions}

\section{Effect of pH}

The effect of initial $\mathrm{pH}$ on the absorption of $\mathrm{Zn}, \mathrm{Cd}, \mathrm{Pb}, \mathrm{Cu}$ and $\mathrm{Cr}$ at $100 \mathrm{mg} / \mathrm{l}$ on A.flavus and A.fumigatus was investigated at $26 \pm 02^{\circ} \mathrm{C}$. As can be seen from (Fig:3a,b) biosorption of $\mathrm{Zn}$ and $\mathrm{Cd}$ ions increased with solution $\mathrm{pH}$ up to 6.0 and biosorption of $\mathrm{Pb}, \mathrm{Cu}$ and $\mathrm{Cr}$ ions increased with solution pHupto 5.0 in A.flavus. There were wide variations in the initial $\mathrm{pH}$ during the biosorption process. The maximum biosorption capacity by biosorbent on different metals were noted as $45 \%, 34 \%$ of $\mathrm{Zn}$ and $58 \%, 38 \%$ of $\mathrm{Cd}$ by A.flavus and A.fumigatus with $\mathrm{pH}$ of the solution at 6.0, Whereas the optimal $\mathrm{pH}$ for biosorption of heavy metals like $\mathrm{Pb}, \mathrm{Cu}$ and $\mathrm{Cr}$ were noticed as $72 \%, 46 \%$ and $44 \%$ respectively with the $\mathrm{pH}$ of the solution upto 5.0 in A.flavus.

Whereas biosorption of heavy metals like $\mathrm{Zn}$ $58 \%$ and $\mathrm{Cd} 38 \%$ in A.fumigatus with the $\mathrm{pH}$ of the solution up to 6.0. The $\mathrm{pH}$ dependency of metals up take by A.fumigatus shows little higher percentage as $\mathrm{Zn} 58 \%, \mathrm{Cd} 38 \%, \mathrm{~Pb}$ $76 \%, \mathrm{Cu} 46 \%$ and $\mathrm{Cr} 44 \%$ at $\mathrm{pH}$ 5-6.0 like as that of A.flavus. The $\mathrm{pH}$ of the biosorption medium affects the solubility of metal ions and the ionization state of the functional groups (ie. Amine, carboxylate and phosphate groups) of the fungal cell wall (Arica et al., 2003). Because of high concentration of protein at lower $\mathrm{pH}$, heavy metal biosorption decreases due to the positive charge density on metal binding sites, ie. Hydrogen ions complete effectively with metal ions in binding to the sites. The negative charge density on the cell surface increases with increasing $\mathrm{pH}$ due to deprotonating of the metal binding sites. The metal ions their complete more effectively for available binding sites, which increases biosorption (Kapoor and Viraraghavan, 1997; Kapoor et al., 1999). 
Table.1 Physical-chemical characteristics of untreated pulp paper mill effluent

\begin{tabular}{|c|c|}
\hline Parameters & Properties \\
\hline Colour & Black \\
\hline pH Value @25ㄷ & 6.21 \\
\hline Turbidity & 41.4 \\
\hline Total Dissolved Solids & 3126 \\
\hline Calcium as $\mathrm{Ca}$ & 533 \\
\hline Magnesium as Mg & 20.6 \\
\hline Reactive Silica SiO2 & 540 \\
\hline Chemical oxygen demand & 531 \\
\hline $\begin{array}{l}\text { Bio - Chemical Oxygen demand ( } 3 \\
\text { days @ } 27^{\circ} \mathrm{C} \text { ) }\end{array}$ & 387 \\
\hline Chlorides as $\mathrm{Cl}^{-}$ & 612 \\
\hline Sulphates as $\mathrm{SO}_{4}^{2-}$ & 531 \\
\hline Potassium as $\mathrm{K}$ & 387 \\
\hline Sodium & 531 \\
\hline
\end{tabular}

Table.2 Heavy metal characteristics of untreated mixed Paper mill effluent

\begin{tabular}{|l|c|}
\hline \multicolumn{1}{|c|}{ Parameters } & Mixed paper mill effluent \\
\hline Manganese & 1.815 \\
\hline Zinc & 2.036 \\
\hline Chromium & 1.476 \\
\hline Copper & 1.067 \\
\hline Cadmium & 1.040 \\
\hline Lead & 2.320 \\
\hline
\end{tabular}

Table.3 Removal of heavy metals $\left(\mathrm{mg}^{-1}\right)$ from paper mill effluent treated by Aspergillus flavus and Aspergillus fumigatus

\begin{tabular}{|c|c|c|c|c|}
\hline Heavy metals & $\begin{array}{c}\text { A.flavus treated } \\
\text { effluent }\end{array}$ & $\begin{array}{c}\text { Average \% } \\
\text { Removal }\end{array}$ & $\begin{array}{c}\text { A.fumigatus } \\
\text { treated effluent }\end{array}$ & $\begin{array}{c}\text { Average \% } \\
\text { Removal }\end{array}$ \\
\hline $\mathbf{M n}$ & $1.105 \pm 0.019^{* * *}$ & 60.86 & $1.296 \pm 0.099^{* *}$ & 71.40 \\
\hline $\mathbf{Z n}$ & $1.329 \pm 0.025^{* * *}$ & 64.95 & $1.620 \pm 0.062^{* * *}$ & 79.55 \\
\hline $\mathbf{C d}$ & $0.795 \pm 0.071^{* *}$ & 76.44 & $0.868 \pm 0.013^{* * *}$ & 84.79 \\
\hline $\mathbf{P b}$ & $1.388 \pm 0.021^{* * *}$ & 59.81 & $1.611 \pm 0.015^{* * *}$ & 69.62 \\
\hline $\mathbf{C u}$ & $1.737 \pm 0.202^{* *}$ & 81.27 & $1.688 \pm 0.028^{* * *}$ & 85.83 \\
\hline $\mathbf{C r}$ & $1.634 \pm 0.105^{* *}$ & 34.00 & $1.141 \pm 0.069^{* *}$ & 46.07 \\
\hline$* * * p<0.001 * * * 00.01$ & & & & \\
\hline
\end{tabular}


Fig.1a Biomass of A.flavus treated with different concentration of heavy metals

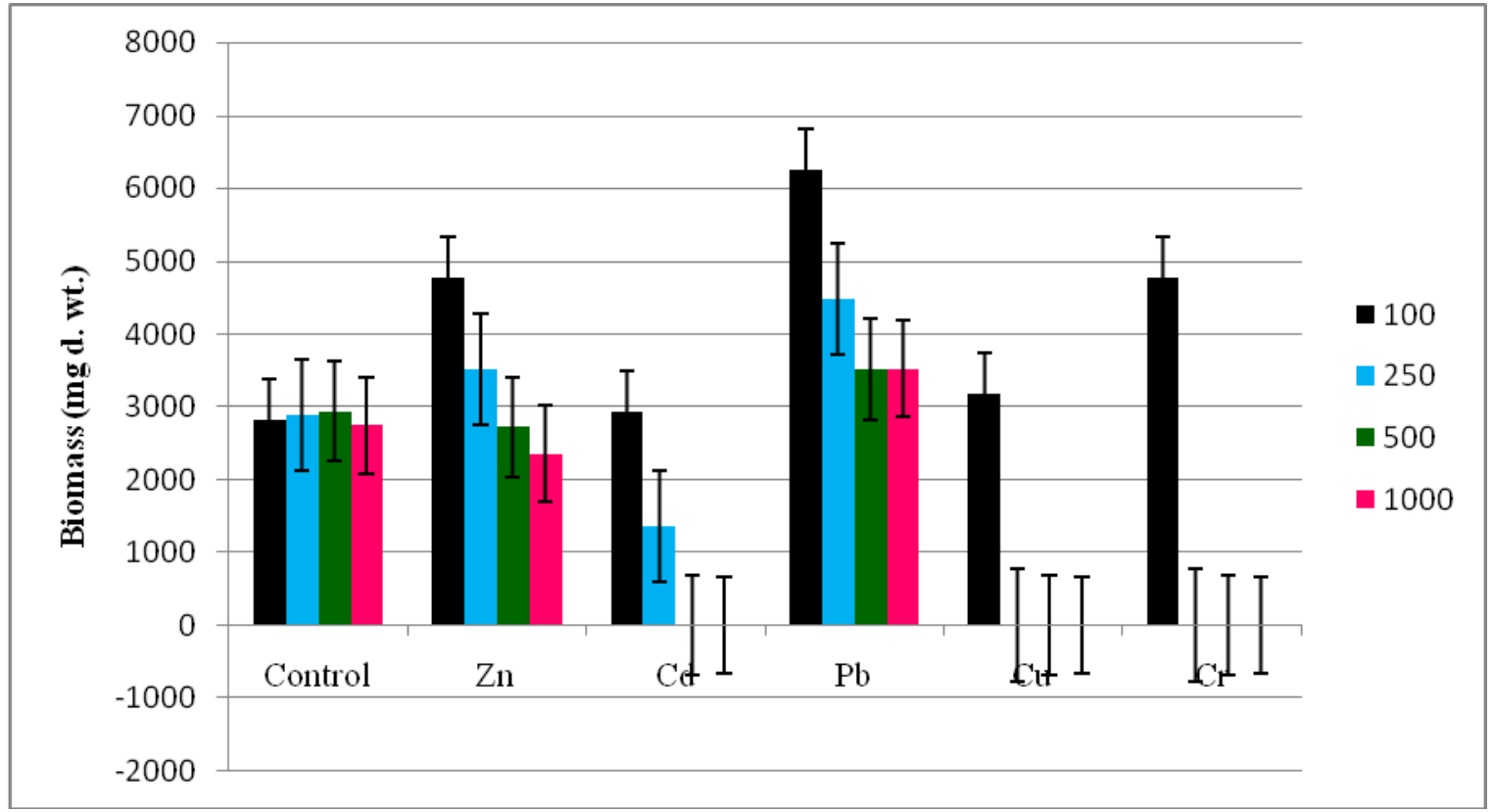

Fig.1b Biomass of A.fumigatus treated with different concentration of heavy metals

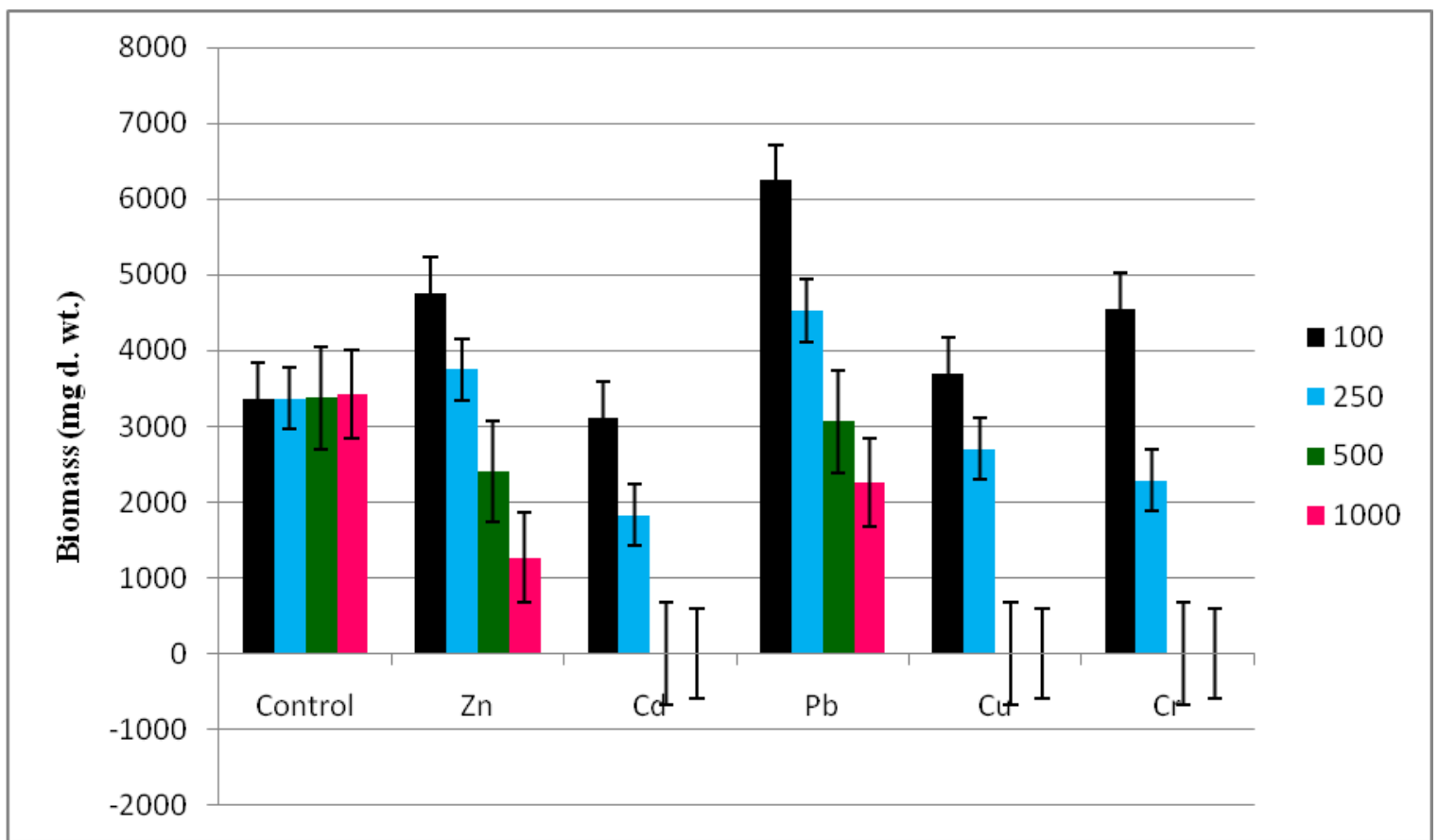


Fig.2a Accumulation of heavy metals (\%) by A.flavus

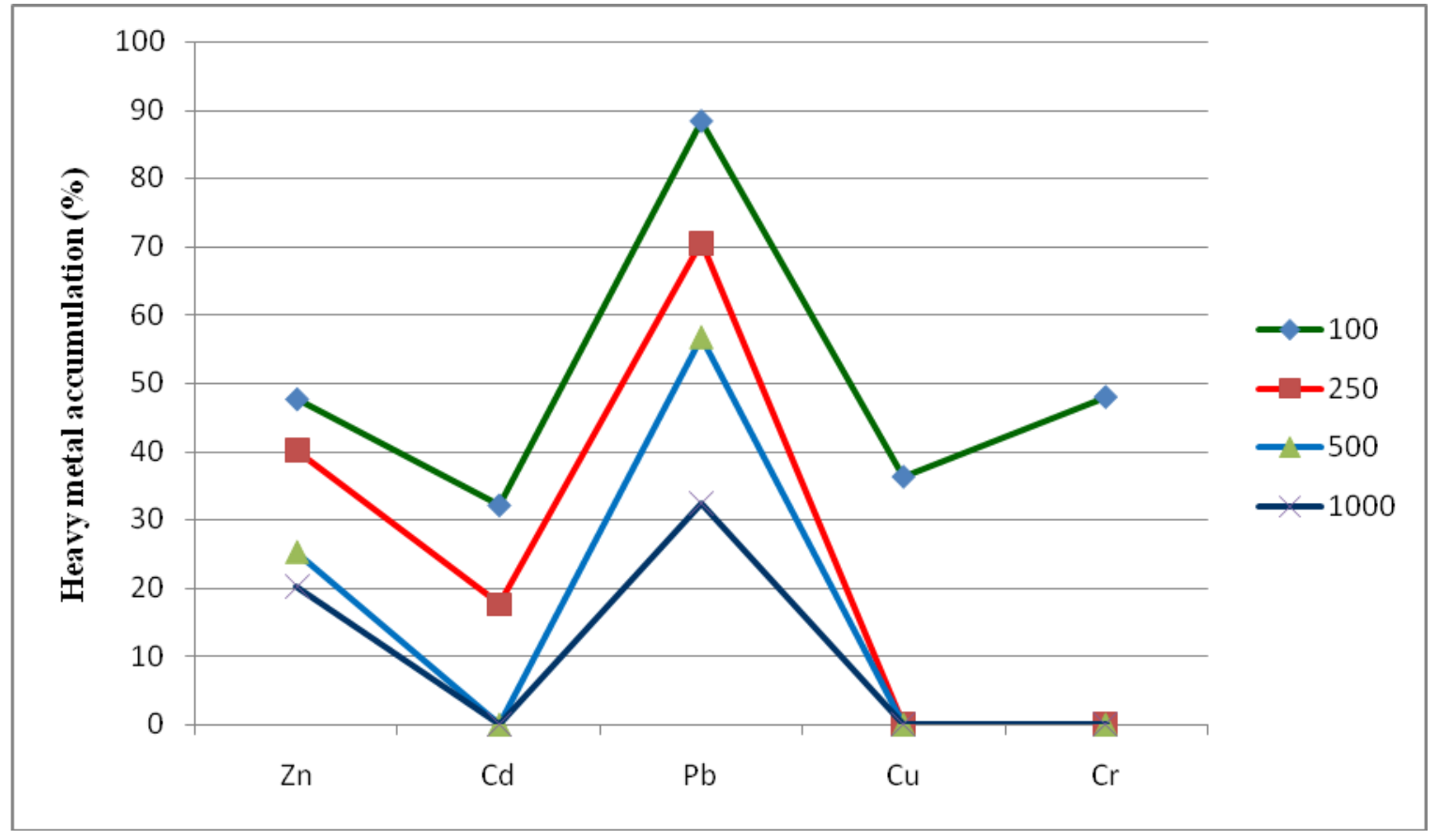

Fig.2b Accumulation of heavy metals (\%) by A.fumigatus

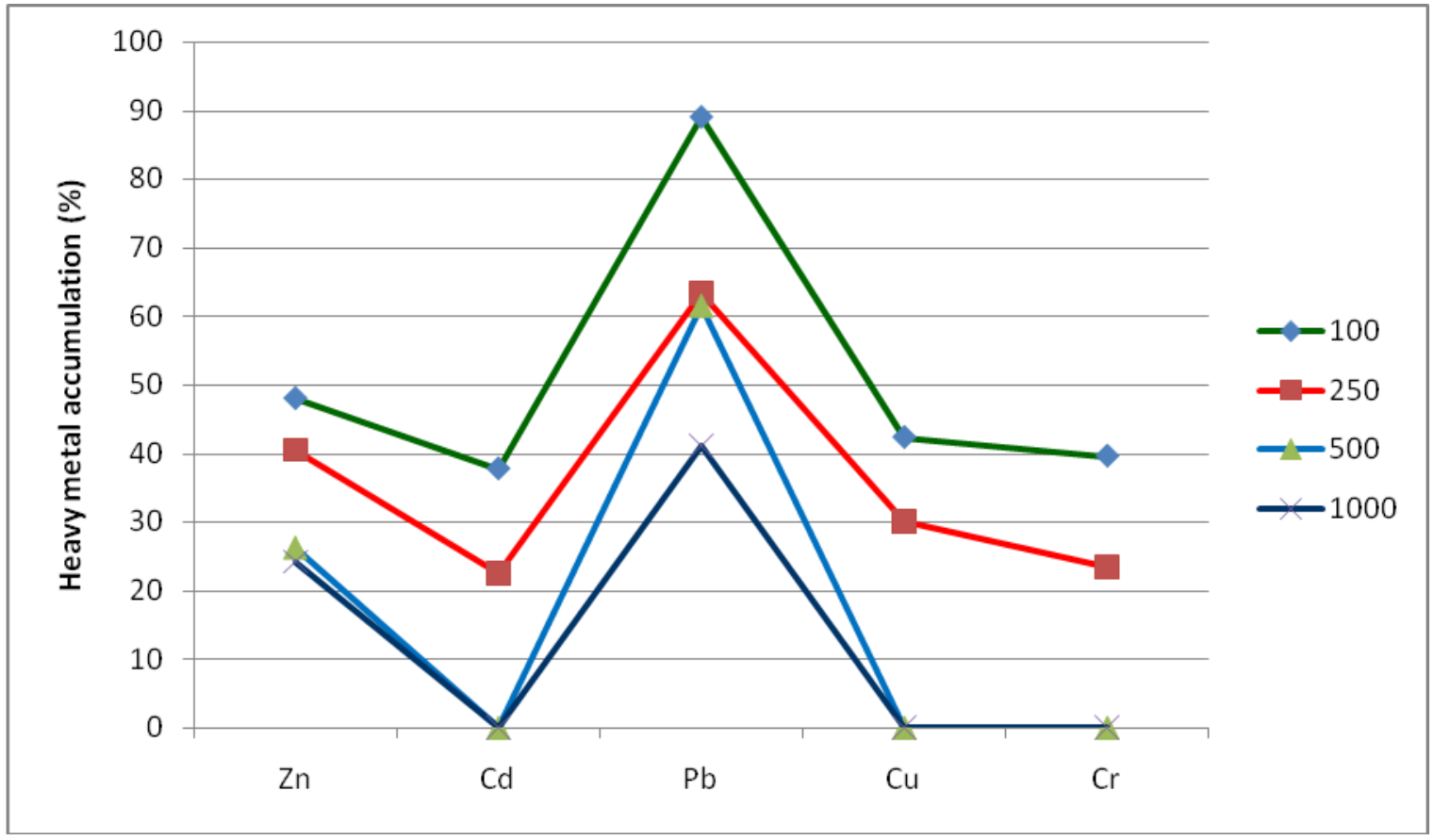


Fig.3a Effect of $\mathrm{pH}$ on metal uptake by A.flavus

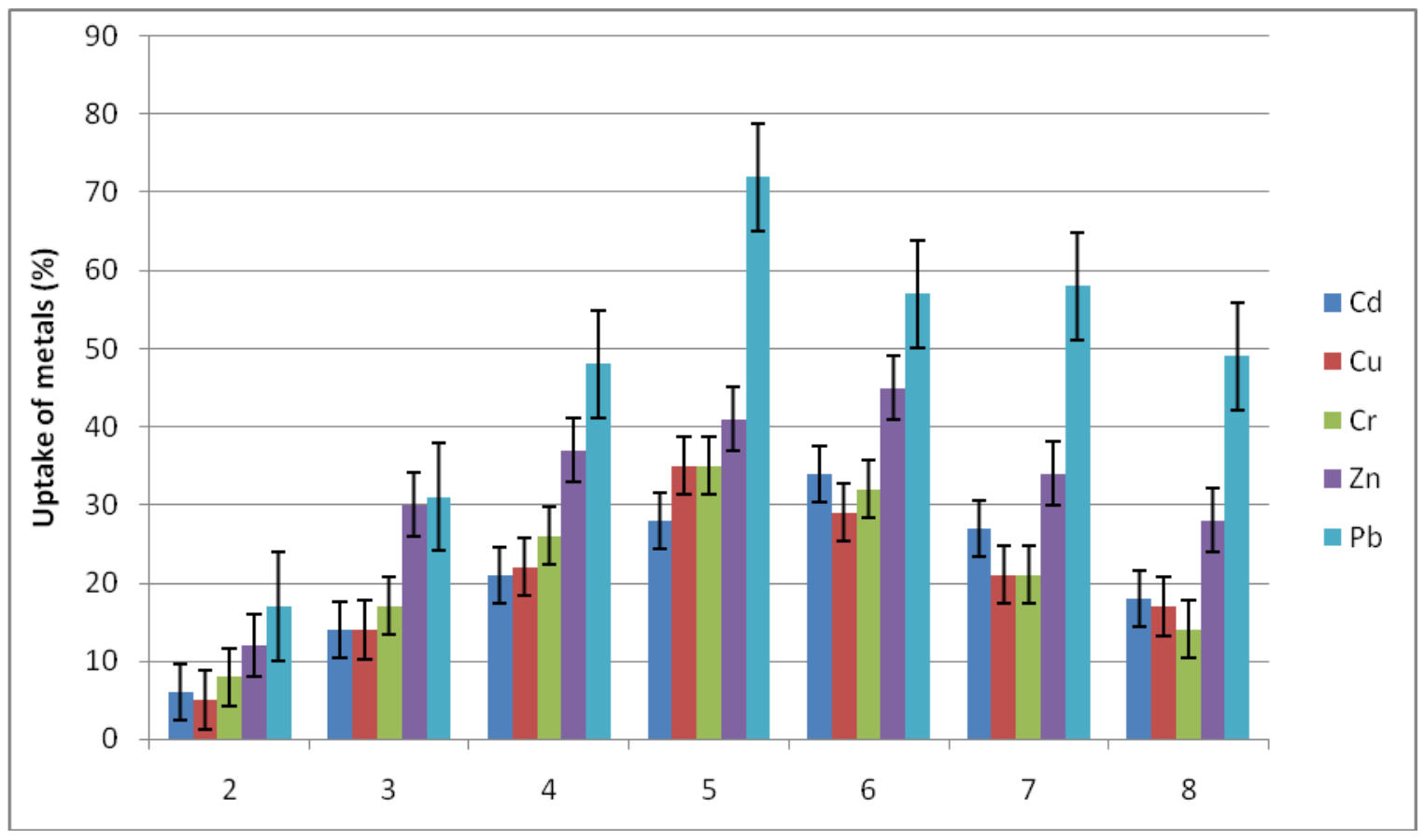

Fig.3b Effect of $\mathrm{pH}$ on metal uptake A.fumigatus

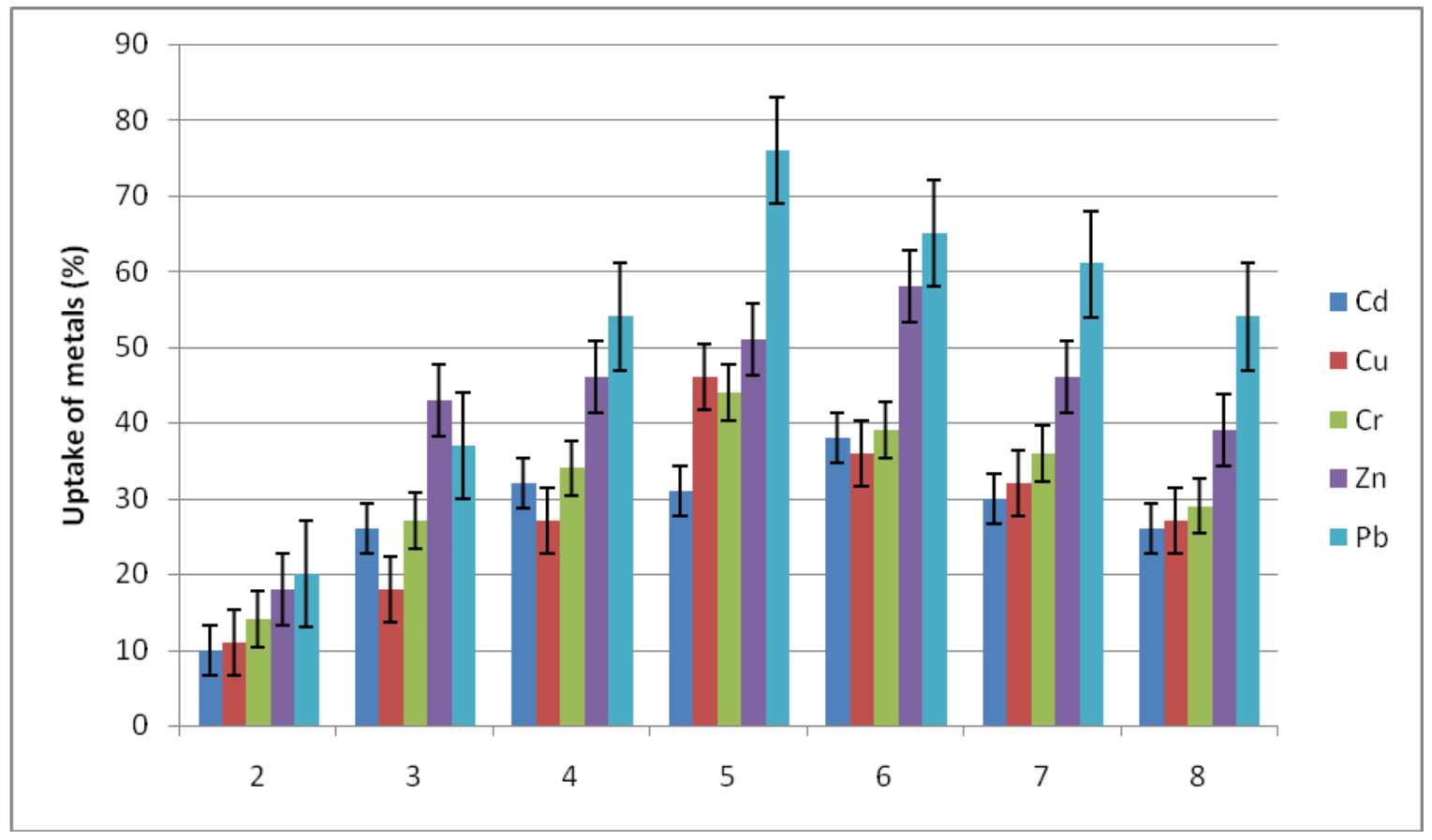


Fig.4a Effect of Temperature $\left({ }^{\circ} \mathrm{C}\right)$ on metal uptake A. flavus

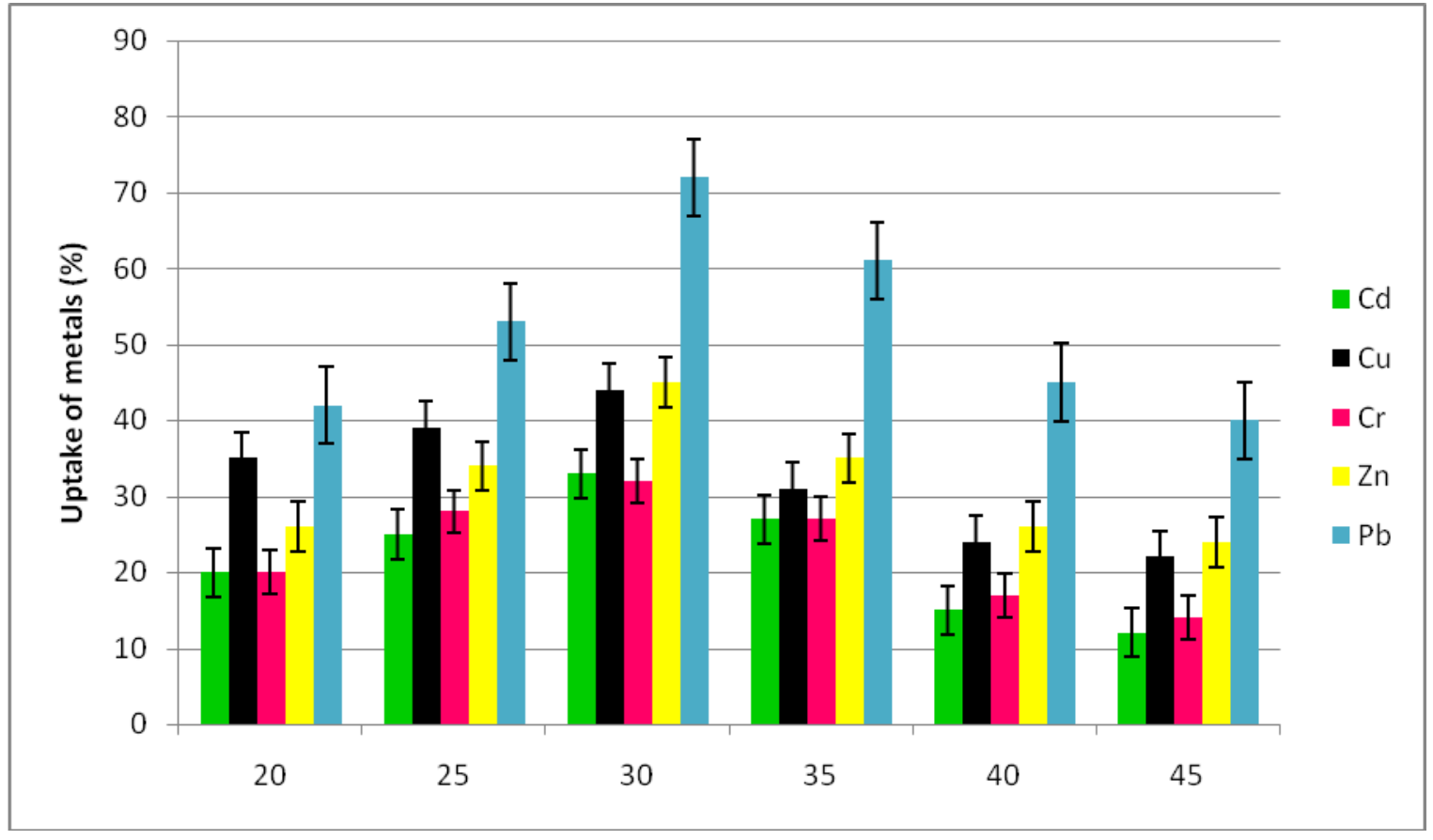

Fig.4b Effect of Temperature $\left({ }^{\circ} \mathrm{C}\right)$ on metal uptake by A.fumigatus

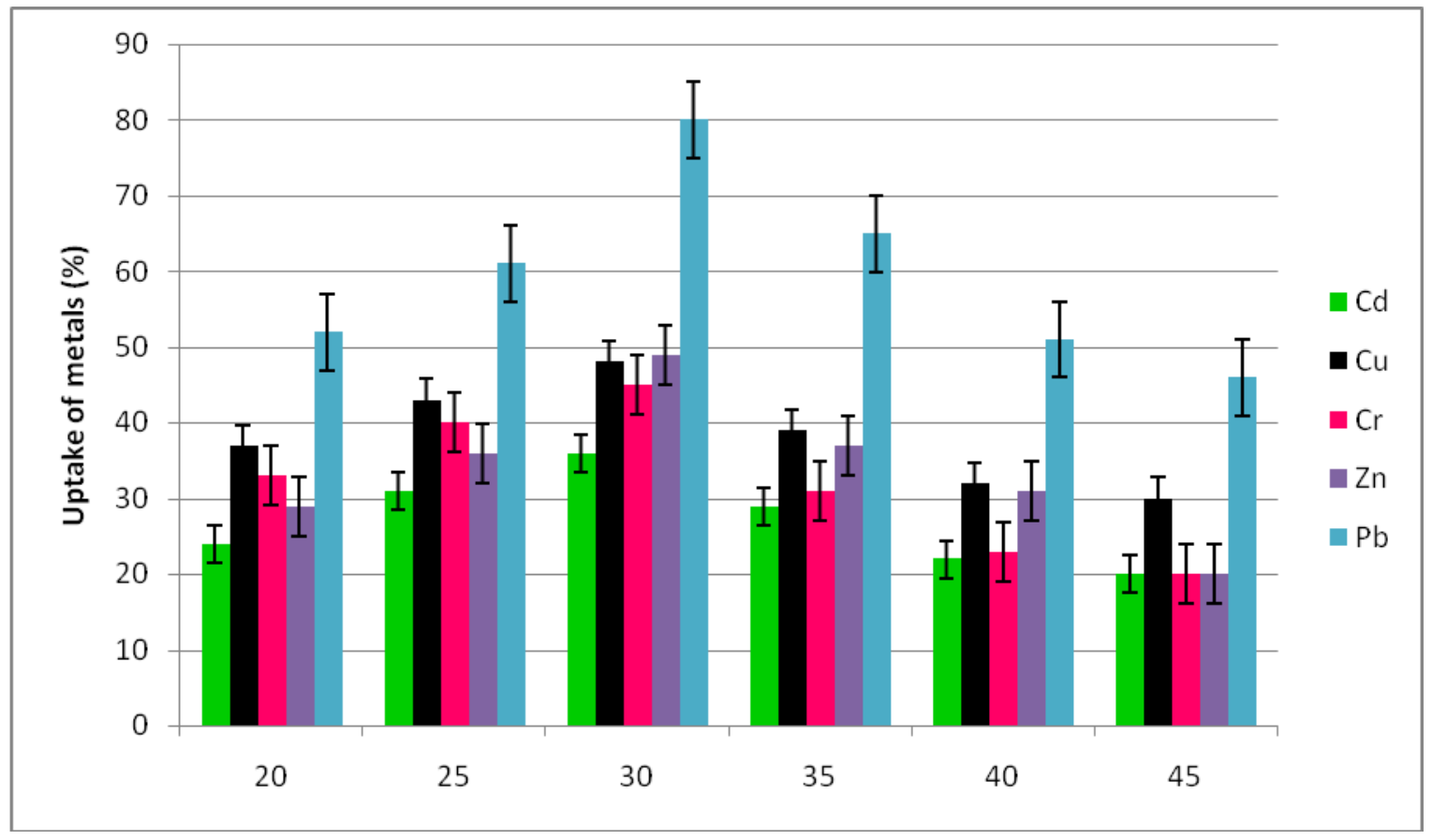


Fig.5a Effect of contact time on bioaccumulation of heavy metals by A.flavus

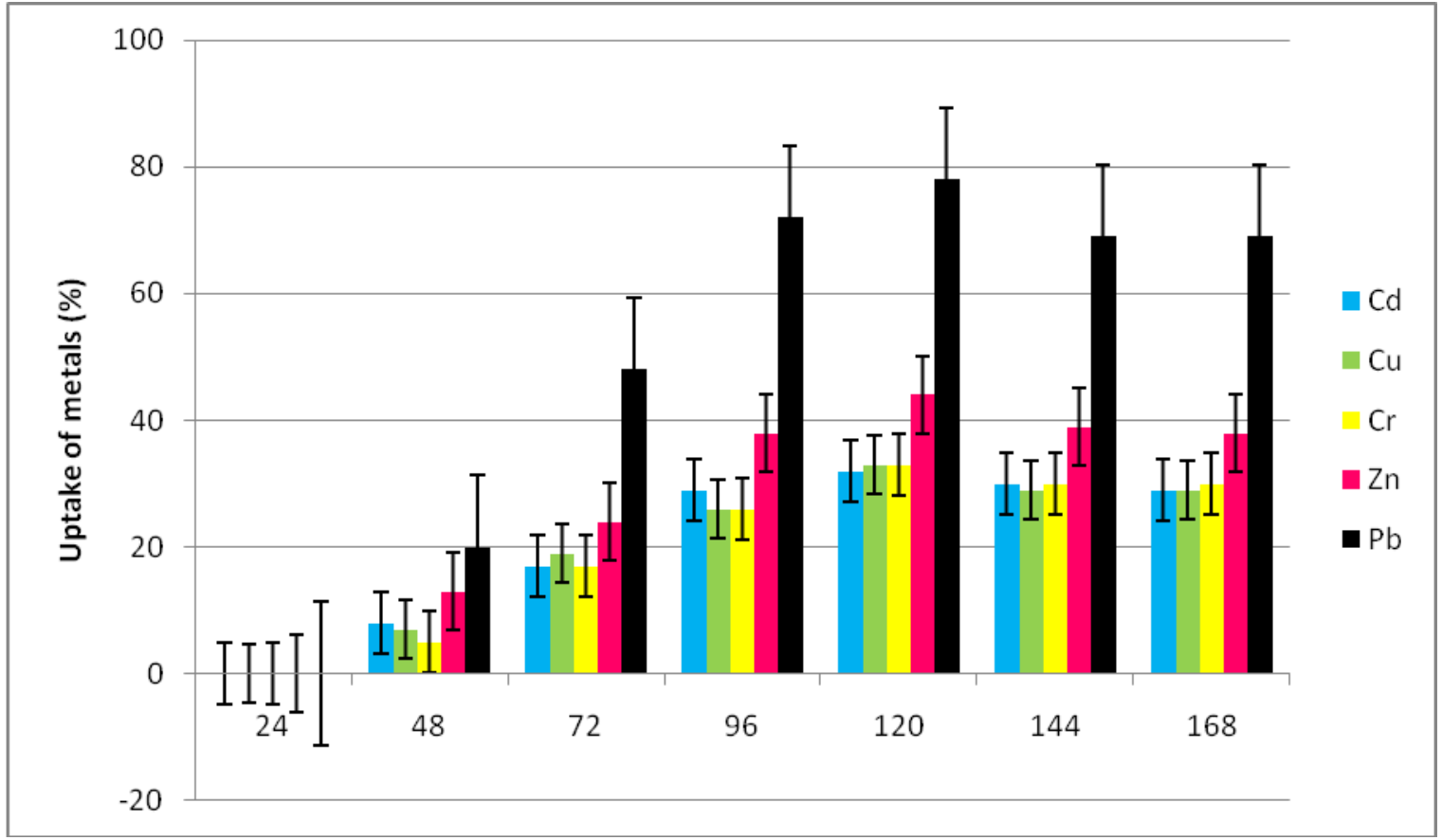

Fig.5b Effect of contact time on bioaccumulation of heavy metals by A.fumigatus

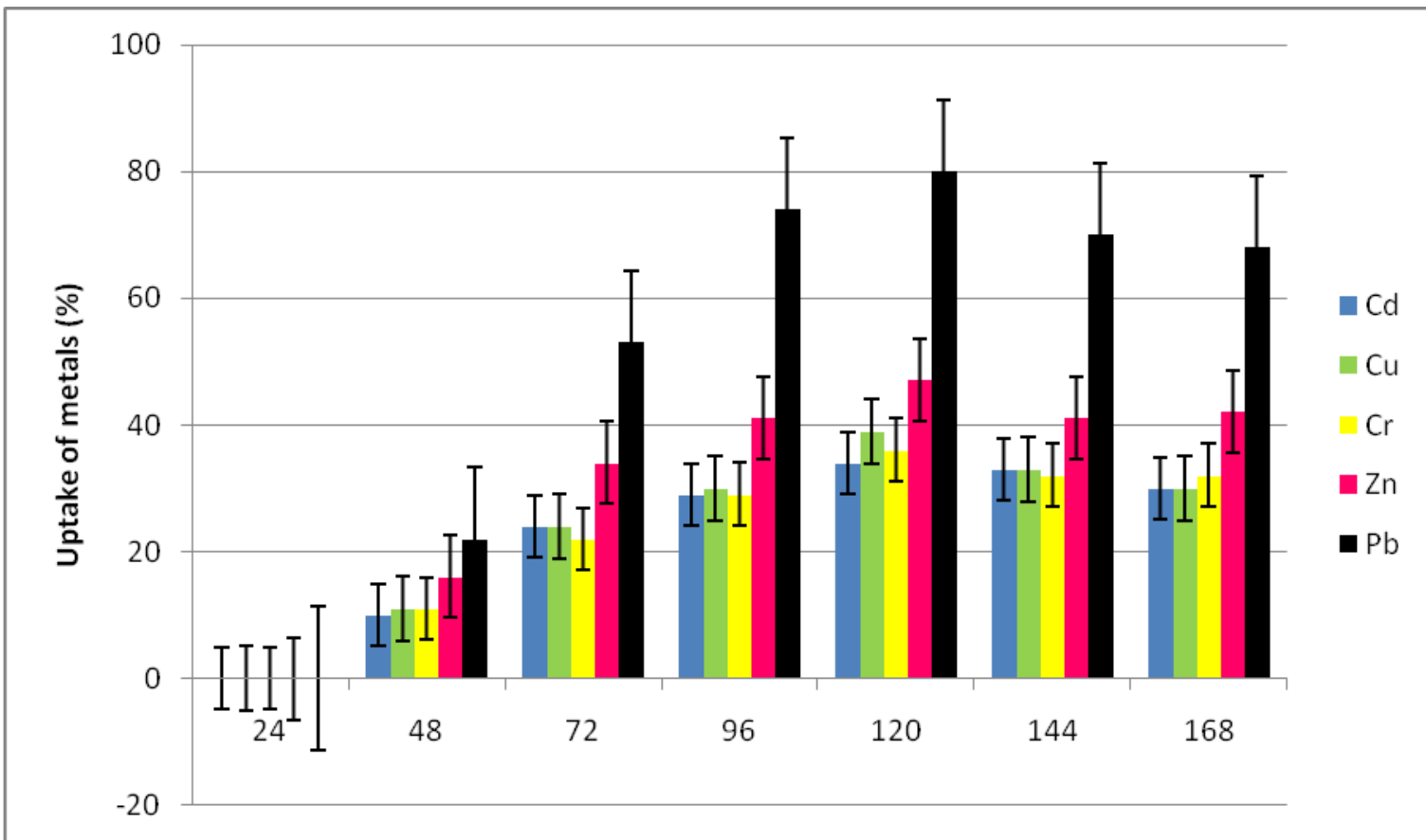




\section{Effect of Temperature}

Temperature is a crucial parameter in adsorption processes. The effect of temperature on the uptake of heavy metals $(\mathrm{Zn}, \mathrm{Cd}, \mathrm{Pb}, \mathrm{Cu}$ and $\mathrm{Cr}$ ) by A.Flavus and A.fumigatus was carried out at different temperature between $20^{\circ} \mathrm{C}$ to $45^{\circ} \mathrm{C}$. It is evident (Fig: 4 a,b) that the adsorption of heavy metals by these fungal biomass increased with increase in temperature between $25^{\circ} \mathrm{C}$ to $30^{\circ} \mathrm{C}$. However subsequent decrease in adsorption capacity was observed when temperature was raised by $35^{\circ} \mathrm{C}$.At high temperature, the attractive forces between biomass surface and metal ions are weakened and the sorption decreases which results in the decrease in the thickness of the boundary layer, due to the increased tendency of the metal ion to escape from the biomass surface to the solution phase. The similar result as decrease in adsorption as temperature increase were reported by (Horsfall and Spiff 2005).

\section{Effect of Contact time}

Bioaccumulation of heavy metals was determined at different incubation period of 24- 168 husing metal solution containing 100 $\mathrm{mg} \mathrm{l}^{-1}$ concentration. It was noticed that under optimum $\mathrm{pH}$ and temperature, the heavy metals accumulation by A.flavus and A.fumigatus was maximum at $120 \mathrm{~h}$ of growth period (Fig. 5a, b). After $120 \mathrm{~h}$ of incubation period, metal accumulation remained constant. Removal efficiency increased with an increase in contact time and this can be explained by the affinity of the adsorbents towards metal ions (Anima et al., 2004).

\section{Removal of heavy metals from untreated paper mill effluent}

Microbes in metal polluted environments adapt to toxic concentration of heavy metals and become metal resistant (Prasenjit and
Sumathi, 2005). In this study, two types of biosorbent of the Aspergillus species were used for the reduction of heavy metals from the mixture of untreated paper mill effluents collected from there sites. The results showed increasing amount of heavy metals had different influence on the fungal biomass and heavy metals accumulation. The isolated fungi indigenous to paper mill sludge were found to reduce some heavy metals at a concentration of $1-3 \mathrm{mg} / \mathrm{l}^{-1}$ present in the pulp and paper mill effluent. Significant $(\mathrm{P}<0.01-0.001)$ reduction of $\mathrm{Cu}(81.27 \%), \mathrm{Cd}(76.44 \%), \mathrm{Zn}(64.95 \%)$, $\mathrm{Mn}(60.86 \%)$ and $\mathrm{Pb}(59.81 \%)$ in the presence of A.flavus. whereas, Significant $(\mathrm{P}<0.01$ $0.001)$ reduction of $\mathrm{Cu}$ (85.83\%), $\quad \mathrm{Cd}$ (84.79\%), $\mathrm{Zn}$ (79.55\%), Mn (71.4\%) and $\mathrm{Pb}$ (69.62\%) in the presence of A.fumigatus. Srivastava et al., (2007) reported that industrial effluent containing toxic organic compounds inhibit the fungal growth but enhance heavy metal biosorption. Similarly in this study the results of heavy metal reduction rate was found to be higher whereas the observed biomass of A.flavus and A.fumigatus decreased and no growth was reported with increased the metal ion concentration of $\mathrm{Cu}$ and $\mathrm{Cd}$. The removal of heavy metal efficiency of A.fumigatus proved superior in removal of $\mathrm{Pb}, \mathrm{Cd}$ and $\mathrm{Cu}$ compared to A.flavus.

Fungi have been identified as superior candidates for metal bioremediation (Bai and Abraham, 2001). The hyper metal tolerant fungi isolated from paper mill effluent sludge has shown vigorous growth in presence of $\mathrm{Zn}^{2+}, \mathrm{Cd}^{2+}, \mathrm{Pb}^{2+}, \mathrm{Cu}^{2+}$ and $\mathrm{Cr}^{2+}$ compared to control fungi without treated with metals. The fungi selected and tested in this study. A.flavus and A.fumigatus have shown unique metal accumulation and tolerance characteristics and easy to culture in sample media. The fungi exhibited high uptake ability for $\mathrm{Pb}, \mathrm{Zn}, \mathrm{Cd}$ and $\mathrm{Cu}$ metals even at concentration of 100 $\mathrm{mg} / \mathrm{L}$. from paper mill effluent and synthetic 
medium. Application of these fungi under optimum conditions such as $\mathrm{pH}$, temperature, contact time and number of metal ions made increased removal of heavy metals and in turn made these fungi to use as alternative adsorbent for conventional methods of effluent treatment.

\section{References}

Akar, T. and Tunali(2006). Biosorption characteristics of Aspergillus flavus biomass for removal of $\mathrm{Pb}$ (II) and $\mathrm{Cu}(\mathrm{II})$ ions from an aqueous Solution. Biores. Technol., 97, 1780-1787.

APHA, (2005). Standard methods for the examination of water and waste water.

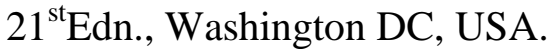

Arica, M. Y., Arpa, C., Ergene, A., Bayramoglu, G., Genc. O (2003). Caalginate as a support for $\mathrm{Pb}(\mathrm{II})$ and $\mathrm{Zn}$ (II) biosorption with immobilized Phanerochaete chrysosporium. Carbohydr. Polym. 52, 167-174.

Bai, R. S., Abraham, T. E., (2001). Biosorption of $\mathrm{Cr}(\mathrm{IV})$ from aqueous solution by Rhizopus nigricans. Bioresource Technology. 97, 17801787.

Chen, C. and J. Wang., (2007). Response of Saccharomyces cerevisiae to lead ion stress. Appl. Microbiol. Biotechnol., 74, 683-687.

Goel, P. K. (1996). Water pollution: Causes, effects and control. New Age International Pvt. Ltd, Publishers, New Delhi.

Juwarkar, A. (1988). Bioaccumulation of Zinc by Penicillium sp. Current Science. 57:251-252.
Kapoor, A. and Viraraghavan, T. (1997). Heavy metal biosorption sites in Aspergillus niger. Bioresour. Technol. 61, 221-227.

Kapoor, A., Viraraghavan, T. and Cullimor, D. R. (1999). Removal of heavy metals using the fungus Aspergillus niger, Bioresource Technology, 70: 95-104.

Leung, W. C., M. F, Wong, H. Chua, W. Lo, P.H.F. Yu and C. K. Leung. (2000). Removal and recovery of heavy metals by bacteria isolated from activated sludge treating industrial effluents and municipal waste water. Wat. Sci. Technol., 41,233-240.

Nagamani, A., I. K. Kunwar and C. Manoharachary. (2006). Hand book of soil fungi. I. K. International Pvt. Ltd., New Delhi.

Prasenjit, B. and S. Sumathi., (2005). Uptake of chromium by Aspergillus foetidus. J. Mater. Cycles Waste Manag. 7:8892.

Srivastava, S., A. H. Ahmad and I. S. Thakur., (2007). Removal of chromium and pentachlorophenol from tannery effluent. Biores. Technol., 98, 112832.

Thippeswamy, B., Shivakumar, C.K. and Krishnappa, M., (2012). Bioaccumulation potency of Aspergillus niger and Aspergillus flavus for removal of heavy metals. Journal of Environmental Biology, 33: 1063-1068.

Verma, V. K., R. K. Gupta and J. P. N. Rai., (2005). Biosorption of $\mathrm{Pb}$ and $\mathrm{Zn}$ from pulp and paper industry effluent by hyacinth (Eichhornia crassipes). J. Sci. Ind. Res., 64, 778-781.

\section{How to cite this article:}

Ezhilvanan, M., S. F. Lesley Sounderraj and Nancy Lesley. 2021. Removal of Heavy Metals using the Isolates of Aspergillus sp. Isolated from Contaminated Pulp and Paper Mill Sludge. Int.J.Curr.Microbiol.App.Sci. 10(04): 890-902. doi: https://doi.org/10.20546/ijcmas.2021.1004.096 